\title{
MUZEA JAKO IDEOLOGICKÝ NÁSTROJ V ČESKOSLOVENSKU V LETECH 1945-1959. PŘíPADOVÁ STUDIE ZNOJEMSKÉHO A MORAVSKOBUDĚJOVICKÉHO MUZEA'
}

PETR BERÁNEK

\section{ABSTRAKT/ABSTRACT:}

Článek má za cíl analyzovat pronikání komunistického diskursu do dvou vlastivědných regionálních muzeí: Jihomoravského muzea ve Znojmě a Krajinského muzea v Moravských Budějovicích v letech 1945-1959. Na jejich rozdílném př́kladě se ukazuje, jak velký vliv měla personální politika a síla regionálních složek KSČ. Vývoj obou muzeí dokumentuje i krizi muzejnictví v 50. letech 20. století.

\section{Museums as an ideological tool} in Czechoslovakia in 1945-1959. A case study of the museums in Znojmo and Moravské Budějovice

The aim of the article is to analyse the penetration of communist discourse into two regional museums of national history: South Moravian Museum in Znojmo and Museum in Moravské Budějovice from 1945 to 1959. Their different examples demonstrate what a big influence the personnel policy and power of regional bodies of the Communist Party of Czechoslovakia have had. The development of both these museums also documents the museum crisis in the 1950s.

1 Studie vznikla z bakalářské práce BERÁNEK, Petr. Muzea jako ideologický nástroj

$v$ komunistickém Československu v letech 1948-1959. Př́padová studie třech moravských muzeí. Brno: Masarykova univerzita, Filozofická fakulta, Ústav archeologie a muzeologie, 2019. Bakalářská práce.

\section{KLÍČOVÁ SLOVA/KEYWORDS:}

Jihomoravské muzeum ve Znojmě Krajinské muzeum v Moravských Budějovicích - dialektický materialismus - historický materialismus - expozice South Moravian Museum in Znojmo Museum in Moravské Budějovice dialectical materialism - historical materialism-permanent exhibitions

Každý radikální posun společenského diskurzu vyvolá rychlou proměnu kolektivní paměti, která velmi záhy začne striktně popírat tu předešlou. Takovým vývojem přirozeně prochází i pamět věcí, institucionálně garantovaná muzei. V druhé polovině 20 . století se muselo české muzejnictví vypořádat se dvěma takovými zlomy spojenými s vítězstvím a úpadkem komunistické moci. Po únoru 1948 se Komunistická strana Československa (KSČ) definitivně snažila vychýlit kolektivní paměti ve svůj prospěch. Právě v první poúnorové dekádě KSČ, státní správa a jí podřízené organizace prosazovaly v muzeích dramatický rozchod s předchozí érou. Její snahy však závisely mnohdy na něčem jiném než na doktrínách, př́kazech Ústředního výboru KSČ, či na propagandě podřízených složek. ${ }^{2}$

2 Tématem proměny muzeí v komunistickém režimu se př́liš̌ autorů nezabývalo. Poúnorovému
Tato studie analyzuje pomocí mikrohistorické sondy konkrétní vliv struktur KSČ na činnost dvou regionálních muzejních institucí v letech 1945 až 1959. Konkrétně se věnuje Jihomoravskému muzeu ve Znojmě a Krajinskému muzeu v Moravských Budějovicích. ${ }^{3}$ Ač obě muzea měla vlastivědný charakter, lišila se velikostí, významem i prostředím. Jihomoravské

vývoji obecně se věnoval Jiří Špét, i když $\mathrm{k}$ tématu přistupoval tendenčně $\mathrm{z}$ pozice badatele 70. a 80. let 20. století. Po roce 1989 Špétovy závěry revidoval Pavel Douša. ŠPÉT, Jiří. Formování a rozvoj socialistického muzejnictví. Praha: Národní muzeum, 1988; ŠPÉT, Jiří.

Formování kulturně politického programu českých muzeí v letech 1945-1954. Muzejní a vlastivědná

práce, 1979, roč. 17, č. 2, s. 92-100; 1979, roč. 17 č. 3, s. 141-145; 1979, roč. 17, č. 4, s. 218-227; ŠPÉT, Jiří. Únor 1948 a české muzejnictví. Časopis Národního muzea, řada historická, 1983, roč. 152, č. 3-4, s. 212-217; DOUŠA, Pavel. Organizace českého muzejnictví 1945-1989. Opava: Slezská univerzita v Opavě, Filozoficko-přírodovědecká fakulta, Ústav historie a muzeologie, 2005. Dizertační práce.

3 Literatura k oběma zmíněným muzeím v tomto období není nijak rozsáhlá a vyčerpávající. ŠEVČÍK, J. 90 let Jihomoravského muzea. Rovnost, 31. 7. 1968, s. 4; Jihomoravské muzeum ve Znojmě. Muzeum - brána poznání. Sborník ke 130. výročí založení. Znojmo: Jihomoravské muzeum ve Znojmě, 2008; k poválečné rekonstrukci pak DRLÍK, Vratislav. 70 let musea královského města Znojma. Znojmo: Městské museum ve Znojmě, 1948. $\mathrm{K}$ historii moravskobudějovického krajinského muzea LOJDA, Vladimír. Muzeum v Moravských Budějovicích. Brno: Masarykova univerzita, Filozofická fakulta, Ústav archeologie a muzeologie, 2011. Magisterská diplomová práce; ČURDA, Jiří. Vývoj expozic muzea $v$ Moravských Budějovicích od jeho založení po současnost. Brno: Masarykova univerzita, Filozofická fakulta, Ústav archeologie a muzeologie, 2008. Bakalářská diplomová práce; VLK, František. Vytváření expozic Muzea Vysočiny Třebíč, Muzea řemesel v Moravských Budějovicích. Moravskobudějovicko. Zpravodaj moravskobudějovického mikroregionu. 2018, roč. 43, č. 4, s. 24; 2018, roč. 43, č. 5, s. 22-23. 
muzeum ve Znojmě zastupuje typ významného městského muzea bývalé jazykově smíšené oblasti, které se proměnilo ve veliký okresní ústav s několika profesionálními zaměstnanci. Krajinské muzeum v Moravských Budějovicích reprezentuje nejhojněji rozšířený typ muzea na Moravě. Jednalo se o instituci fungující na dobrovolnickém principu a působící v hranicích příslušného soudního okresu. V 50. letech se z něj stalo okresní muzeum s jedním stálým pracovníkem.

Případová studie se opírá vedle vývoje obou institucí i o stručný kontext zahrnující společenský diskurz, komunistické snahy proměnit muzea $\mathrm{v}$ poslušný ideologický nástroj a v neposlední řadě tehdejší muzeologické tendence. Komparace obecných trendů a konkrétního vývoje zmíněných muzeí tak ukazuje reálný obrat paměti věcí.

\section{Poválečná obnova muzeí}

Po osvobození se obě muzea snažila přirozeně navázat na svoji předválečnou minulost. Projevilo se to zejména $\mathrm{v}$ personální rovině. Obnovy moravskobudějovického krajinského muzea se ujal František Jech, meziválečný dobrovolný správce a místní středoškolský profesor. ${ }^{4}$ Ve znojemském městském muzeu byla situace složitější kvůli jeho částečně německojazyčné kulturní minulosti. ${ }^{5}$ Zpočátku

\footnotetext{
4 Již před nacistickou okupací se v okresním městě nacházelo krajinské muzeum zřízené muzejním spolkem, respektive kuratoriem jako jeho výkonným orgánem. Po celou meziválečnou dobu byl dobrovolným správcem František Jech, místní gymnaziální profesor. Muzeum sídlilo na starém okresním hejtmanství, ale po obsazení pohraničí v roce 1938 muselo budovu uvolnit pro uprchlíky ze Znojemska. Za protektorátu zůstaly předměty uložené $\mathrm{v}$ bývalém skladu papíru. Muzeum Vysočiny Třebíč - Knihovna Muzea řemesel Moravské Budějovice (MVT - PMB). JECH, František. Pamětní kniha Moravských Budějovic II/2. (1926-1938), s. 512, fotokopie.

5 Instituce již před válkou patřila městu a její chod řídilo kuratorium, do nějž nominovalo členy město a německý měštanský spolek. DRLÍK,
}

muzeum převzal od místního národního výboru (MNV) František Dostál, jeho bývalý předválečný český správce, který bydlel s výjimkou let 1938-1945 přímo na Znojemském hradě. ${ }^{6}$ Toto řešení se ukázalo vzhledem k významu a velikosti znojemského muzea trvale neudržitelné. Ještě v létě 1945 MNV jmenovalo bývalého nejvýznamnějšího českého předválečného člena muzejního kuratoria Františka Vildomce, archeologa a učitele, jako kustoda muzea. Svoji funkci vykonával pouze do prosince 1946, kdy se místa vzdal kvůli neshodám s MNV ovládaným KSČ a se správcem Dostálem. ${ }^{7}$

Vratislav Drlík, Vildomcův následovník, odpovídal představám MNV i poválečnému diskurzu, ač mu chyběla kontinuita s muzeem. Drlík, řídící učitel obecné školy ve Znojmě-Louce, představoval typ nacionalisticky orientovaného komunisty s předválečnými zkušenostmi z jazykově smíšené periferie Československa. Jeho osoba nabyla navíc na

Vratislav. 70 let musea královského města Znojma. Znojmo: Městské museum ve Znojmě, 1948, s. 6.

6 Moravský zemský archiv v Brně, Státní okresní archiv Znojmo (MZA, SOkA Znojmo), fond Jihomoravské muzeum Znojmo (1945-2002), karton 10, i. č. 654, složka: Snížení počtu administrativních zaměstnanců ve st. správě plán potřeby stálých pracovníků 1951, Seznam zaměstnanců Městského musea ve Znojmě k 1. VII. 1951, nefoliováno; MZA, SOkA Znojmo, fond Jihomoravské muzeum Znojmo (1945-2002), karton 11, i. č. 734, složka: Dostál František, fol. 1-51.

7 Oficiálním důvodem odchodu mělo být Vildomcovo dojíždění, respektive nemožnost bydlení ve Znojmě. Vildomcův syn Vědomil vzpomínal, že ve skutečnosti šlo o spory se znojemskou MNV, která přes jeho přání odmítla zaměstnávat bývalého německého ředitele Tomáška. Dalším důvodem bylo právě jmenování Dostála správcem. Vildomec v něm viděl ohrožení sbírek, jelikož Dostál je považoval částečně za svůj majetek. Údajně ho však nejvíce rozčílilo, když mu MNV chtělo přidělit vilu u Obří hlavy. Vildomec totiž nechtěl zabírat honosnou stavbu, ale chtěl poctivě pracovat. PODBORSKÝ, Vladimír. František Vildomec (6. 2. 1878 - 3. 11. 1975). Venkovský učitel, vlastivědný pracovník a věhlasný archeolog. Vědomil Vildomec (27. 9. 1921 28. 12. 1998). Syn věhlasného archeologa, kantor, muzejník, archeolog a kulturně-osvětový pracovník Brno: Ústav archeologické památkové péče v Brně a Ústav archeologie a muzeologie FF MU v Brně, 2005, s. 122 . důvěryhodnosti i kvůli věznění v době nacistické okupace. ${ }^{8}$ Drlíkova osobnost tak vyhovovala nacionální rétorice KSČ druhé poloviny 40 . let, kdy vystupovala jako síla završující národní revoluci. ${ }^{9}$

Prioritu obou muzeí v tomto období představovala rychlá obnova činnosti. Krajinské muzeum, provozované spolkem, se snažilo získat pro znovuzřízení podporu MNV, proto ještě v roce 1945 rozšíríilo prozatímní kuratorium muzea své řady o čtyři zástupce Národní fronty - vždy o jednoho zástupce politické strany. Kuratorium, které postrádalo jakoukoli budovu, se navíc rozhodlo na Jechův popud zažádat MNV a ministerstvo zemědělství o přidělení konfiskovaného zámku. Aby jejich žádost byla kladně vyřízená, získali podporu moravskobudějovického rodáka a pracovníka Národního muzea Josefa F. Svobody, Alberta Kutala z Moravské zemské obrazárny. Kuratorium apelovalo i na Státní památkovou správu a Státní zemědělský archiv. Ministerstvo nakonec vyhovělo žádosti začátkem roku 1946 a přidělilo objekt zámku a pozemky MNV za podmínky, že samotná budova zámku bude použita pro muzejní nebo jiné kulturní účely. ${ }^{10}$

8 Vratislav Drlík (1886-1955) pocházel z národnostně smíšeného Zábřežska; za první světové války se jako příslušník ruských legii zapojil do vzpoury levicově smýšlejícího proudu v Irkutsku v roce 1919. Po návratu do ČSR pomáhal čechizovat Šumpersko až do roku 1933, kdy odešel do Znojma. Zde byl členem místní buňky KSČ. Za nacistické okupace byl zatčen a přes dva roky až do osvobození strávil v koncentračním a pracovních táborech. Po návratu do Znojma nastoupil zpět do školy ve Znojmě-Louce a později jako člen MNV. K Drlíkově životu viz KLEJDUS, Julius a Lea MAŇÁKOVÁ. Vratislav Drlík - učitel, přírodovědec a spoluzakladatel Jihomoravského muzea ve Znojmě. Thayensia-Supplementum 1, 2005, s. 3-6.

9 KUSÁK, Alexej. Kultura a politika

v Československu 1945-1956. Praha: Torst, 1998, s. 153.

10 Moravský zemský archiv v Brně, Státní okresní archiv Třebíč, pracoviště Moravské Budějovice (MZA, SOkA Třebíč), fond Krajinské muzeum Moravské Budějovice, Kniha Zápisy o schůzích 
Členové kuratoria si uvědomovali, že oprava a údržba budovy zámku bude nad možnosti spolku, proto ještě na jaře 1946 prosadil Jech revizi muzejního řádu $\mathrm{z}$ roku 1926. Žádal v ní, aby se MNV stal vlastníkem muzea s právem „ustanoviti organisaci musea.“11 MNV nový řád akceptoval až v ř́ijnu 1946, ve výsledku do chodu kuratoria nezasahoval a poskytoval finanční krytí oprav. ${ }^{12} \mathrm{~V}$ říjnu 1947 muzeum slavnostně otevřelo osm místností nových expozic kombinujících otevřený depozitář a památkově interiérovou instalaci. ${ }^{13}$

Výchozí pozice znojemského muzea byla příznivější než u moravskobudějovického protějšku. Znojemská instituce využívala objekt znojemského hradu již z předválečných let a měla zřizovatelskou podporu MNV včetně několika placených zaměstnanců. Po odstranění většiny válečných škod a návratu sbírek z improvizovaných krytů se podařilo otevřít první muzejní instalaci v červenci $1946 .{ }^{14}$ Následující rozšíření instalací a úpravy si nicméně vyžádaly další finance, které Drlík zajištoval především od MNV, menší měrou pak ze státní subvence ${ }^{15}$

kuratoria měst. Musea v Mor. Budějovicích, Zápis z 25. 7. 1945 a Zápis z 13. 3. 1946.

11 MZA, SOkA Třebíč, fond Krajinské muzeum Moravské Budějovice, Kniha Zápisy o schůzích kuratoria měst. Musea v Mor. Budějovicích, Zápis z 12. 4. 1946.

12 MVT - PMB. JECH, František. Pamětní kniha Moravských Budějovic III/2 (1945-1955), s. 332, fotokopie.

13 ČURDA, Jiří. Vývoj expozic muzea $v$ Moravských Budějovicích od jeho založení po současnost. Brno: Masarykova univerzita, Filozofická fakulta, Ústav archeologie a muzeologie, 2008, s. 17. Bakalářská diplomová práce.

14 Znojemské museum. Týdeník pro pohraničí, 1946, roč. 2, č. 27, 6. 7. 1946, s. 1. Ke škodám na Znojemském hradě viz DRLÍK, Vratislav. 70 let musea královského města Znojma. Znojmo: Městské museum ve Znojmě, 1948, s. 63-65.

15 V roce 1946 činila státní podpora 40 000,Kč. Archiv Moravského zemského muzea, fond Moravské zemské muzeum, 1947, krabice 39, složka: 734/1947 Musea mor.-slezská-subvence ZNV za 1947, nefoliováno. a od Zemského národního výboru v Brně (ZNV). ${ }^{16}$ V květnu 1947 se Drlíkovi podařilo otevřít na hradě další expozice, jejich idea se však ještě opírala více o předválečnou koncepci než o nastupující trend takzvané lidovýchovy.

V té době již přední významní muzejníci prosazovali novou moderní prezentaci včetně dočasných výstav, v níž „musea mají zpřistupniti lidu velké myšlenky a ideje a musí se jeviti jako oddaný služebník národu a společnosti a účastniti se plně života $v$ př́tomnosti“. ${ }^{17}$ Ve stejném duchu se vyjadřoval i budovatelský program Gottwaldovy vlády v červenci 1946. V něm se objevil požadavek „,zajistiti intensivní provádění všeobecné lidovýchovy jakožto důležitého činitele při výstavbě státu a při snaze o dosažení demokratické vyspělosti širokých vrstev našeho lidu. "18 Shoda odborníků s vládní KSČ se nicméně zakrátko ukázala jako iluze. Zatímco jedni chtěli posílit primárně vzdělávací roli muzea, druzí jej chtěli proměnit $\mathrm{v}$ propagandistickou instituci.

Při obnově se Jech i Drlík přiklonili ke konzervativní expoziční koncepci z několika důvodů. V prvních poválečných letech se nový prezentační směr teprve formoval a Jech i Drlík při rychlé obnově muzeí neměli o něm ještě dostatek konkrétních informací. Jech navíc setrvával na myšlence muzea jako otevřeného depozitáře či památkově interiérové instalace, protože stavěl na své předválečné zkušenosti tvůrce spolkového

\footnotetext{
16 Za rok 1946 mělo muzeum výdaje ve výši téměř 249000 Kč. Subvence od ZNV činila 10000 Kč především na restaurování a nákup odborné literatury. Moravský zemský archiv v Brně (MZA), fond B 280 Zemský národní výbor Brno, karton 1841, složka VII-15a (1945-1949), fol. 278-281.

17 SKUTIL, Josef. Sociální a kulturní poslání musea. Svobodné noviny, 9. 9. 1945, s. 3.

18 Budovatelský program Gottwaldovy vlády. Praha: Ministerstvo informací, 1946, s. 24.
}

muzea. Drlík se snažil naproti tomu jen dokončit již započatou práci svých předchůdců, přitom pracoval na zavedení nového kulturně vzdělávacího trendu.

Zhmotněním myšlenky se měl stát nastupující fenomén dočasných výstav, aby se muzeum nestalo „tím, čím bohužel ještě dnes většina krajinských museí je: museum které stačí navštívit jednou za život, protože se tam stejně nikdy nic nového neuvidí. Správa musea si je dobře vědoma výchovného poslání této instituce a podle toho také řidí svou práci“. ${ }^{19}$ Se znovuotevřením nabídla instituce návštěvníkům vedle stálých expozic i dočasnou výstavu věnovanou současným jihomoravským výtvarníkům. ${ }^{20}$ Muzeum pak nabízelo až čtyři výstavy ročně, vesměs historické, umělecko-historické či umělecké, $\mathrm{Z}$ nichž většinu připravovalo samo. ${ }^{21}$

V prvních dvou letech po otevření přistupovalo moravskobudějovické muzeum k otázce putovních výstav konzervativně. V největším sále muzea vznikla umělecká galerie, tedy nikoli prostor pro dočasné výstavy muzejního charakteru. V této místnosti se tak prezentovaly nejprve obrazy malíře a Jechova gymnaziálního kolegy Františka Šindeláře a následující rok 1948 dílo malíře Josefa Klimeše. Vedle Klimešových obrazů muzejní pracovníci připravili malou výstavu archiválií k revolučnímu roku $1848 .^{22}$ Výstavka byla

\footnotetext{
19 HRUBEC, Karel. Znojemské museum kdysi a dnes. Stráž na Dyji, 1946, roč. I, č. 1, 6. 10. 1946 , s. 3.

20 K výstavě Jihomoravští výtvarníci ve znojemském museu. Stráž na Dyji, 1946, roč. I, č. 1, 15. 9. 1946, s. 4.

21 Znojemsko. Výroční zpráva musea král. města Znojma za rok 1947. Naše demokracie. List Československé strany lidové na jihozápadní Moravě, 1948, roč. 4, č. 5, 30. 1. 1948, s. 6.

22 Moravsko-Budějovicko. Krajinské museum v Mor. Budějovicích otevřeno. Naše demokracie. List Československé strany lidové na jihozápadní Moravě, 1947, roč. 3, č. 39, 10. 10. 1947, s. 4; MZA, SOkA Třebíč, fond Krajinské muzeum Moravské Budějovice, Kniha Musejní deník - práce I, 1947.
} 
pravděpodobně první reakcí na sílící požadavek po vzdělávání veřejnosti pomocí dočasných výstav.

\section{Nástup KSČ k moci}

Únorový převrat KSČ se bezprostředně projevil $\mathrm{v}$ muzejnictví různou měrou „vyakčňování“, to jest čistkami v podobě vynucených penzionování, pracovních výpovědí či přemístění na perspektivnější pozice. Napřriklad Moravské zemské muzeum patřilo $\mathrm{v}$ tomto ohledu mezi nejhůře zasažené. ${ }^{23} \mathrm{~V}$ protikladu k tomu zasáhly únorové události do chodu znojemského i moravskobudějovického muzea minimálně, protože místní struktury KSČ neviděly v personální rovině zásadní problém.

Znojemské muzeum řídil Vratislav Drlík, komunista s vazbami na MNV, tudíž radikální zásah ztrácel smysl. Paradoxně došlo pouze k rozšíření personálu o jednoho pracovníka. Začátkem března 1948 nastoupil do muzea jako laborant Bohumil Zavřel, člen KSČ s dělnickým původem, kterému nicméně chybělo vzdělání i zručnost, proto v muzeu vykonával pouze neodborné práce. ${ }^{24}$ Regionální vedení KSČ zřejmě Zavřela „uklidilo“ do muzea pro jeho charakterové vady. ${ }^{25}$

V moravskobudějovickém případě se zase ukázala mocenská slabost místní KSČ. Místní akční výbor Národní fronty shledal, že všichni

23 MIKULKA, Jiří. K historii Moravského zemského muzea v letech 1945-1949. Časopis Moravského muzea, 1995, roč. 80, s. 253-261.

24 MZA, SOkA Znojmo, fond Jihomoravské muzeum Znojmo (1945-2002), karton 10

i. č. 654 , složka: Snížení počtu administrativních zaměstnanců ve st. správě - plán potřeby stálých pracovníků 1951, nefoliováno; MZA, SOkA Znojmo, fond Jihomoravské muzeum Znojmo (1945-2002), karton 10, i. č. 658, složka: Stav zaměstnanců muzea - sdělení 1954, nefoliováno.

25 K Zavřelovu chování viz MZA, SOkA Znojmo, fond Jihomoravské muzeum Znojmo (1945-2002), karton 11, i. č. 734, složka: Antonín Hudec ředitel muzea 1961, 1952-1963, fol. 5-6. členové kuratoria jsou spolehliví včetně zdejšího římskokatolického děkana a zástupce za lidovou stranu Josefa Opletala. Ten se sám vzdal své funkce na dubnovém zasedání se slovy, že „bude i nyní museum podporovati, pokud mu bude možno."26 Ani na květnové valné hromadě muzejního spolku nedošlo k žádné radikální změně, nebo zásahu ze strany komunistů. Členové spolku zvolili do kuratoria téměř celé dosavadní vedení včetně děkana Opletala. ${ }^{27}$

Setrvačnost předúnorového světa v muzeích měla vzít brzy za své. Již v dubnu 1948 KSČ odhalila na Sjezdu národní kultury svi̊j záměr. Zdeněk Nejedlý, tehdejší ministr školství a osvěty, popsal základní princip, na kterém má stát nová socialistická kultura a věda. Vědecký socialismus podle něj vychází z ideologie, která doplňuje dialektický materialismus. „Naše budoucí věda a umění, veškerá naše kulturní práce nesmí být nahodilá činnost, vydaná napospas náhodám neb zvůli jednotlivců neb skupin bez určitých zásad. Musí být opřena o určitou ideologii, a samozřejmě ideologii, která souhlasí s potřebami naší doby...ideologie je zbraň, a mocná zbraň, zbraň pro výchovu mas, pro výchovu národa, pro výchovu mládeže.“28 Nejedlý tak proměnil původní volání, aby muzea byla lidovýchovnými zařízeními, v požadavek na čistě ideologická centra pro manipulaci s masou.

Rok poté vydal Svaz českých muzeí pod tlakem členů, kteří sympatizovali s politikou KSČ, přílohu spolkového oběžníku, tzv. Rámcový program výstavních sbírek vlastivědných museí. Program

\footnotetext{
26 MZA, SOkA Třebíč, fond Krajinské muzeum Moravské Budějovice, Kniha Zápisy o schůzích kuratoria měst. Musea v Mor. Budějovicích, zápis z 15. dubna 1948.

27 Ibid., zápis z valné hromady z 23. 5. 1948.

28 Sjezd národní kultury 1948. Sbírka dokumentů. Praha: Orbis, 1948, s. 164.
}

se zabýval výstavní prezentací přírodovědných a historických expozic v duchu dialektického a historického materialismu. Základním kamenem nové expoziční koncepce společenskovědních témat byla práce Václava Husy Epochy českých dějin. ${ }^{29}$ Dokument uváděl i příklady sbírkových předmětů pro jednotlivé části. ${ }^{30}$

Právě rámcový program inspiroval Vratislava Drlíka k myšlence vybudovat vzorové expozice ve znojemském muzeu. K záměru mu nahrávalo i to, že muzeum během posledních let rozšírílo svoji kapacitu. V roce 1950 se dokončovala zdlouhavá přestavba budovy bývalého minoritského kláštera, tzv. Frohnfestu, kterou muzeum získalo v roce $1947 .{ }^{31}$ V roce 1949 MNV přidělil ústavu ještě třetí objekt, renesanční měštanský dům, pro účely obrazárny. ${ }^{32}$

\section{V letech 1950 až 1952 se nová} instalace $\mathrm{v}$ marxistickém diskursu stala prioritním úkolem celého muzea. Vratislav Drlík rozdělil expozici po vzoru rámcového programu na přírodovědné oddělení, které mělo být na hradě, a na historické v adaptovaném Frohnfestu. Přírodovědnou část postavil na myšlence dialektického materialismu, který se projevil ve zvýraznění poměru prezentované neživé i živé přírody k člověku, respektive jejich užitečnost pro společnost.

\footnotetext{
29 Husa definoval v útlé brožuře pouze novou periodizaci dějin striktně vycházející z marxleninského diskursu. HUSA, Václav. Epochy českých dějin. Praha: Práce, 1947.

30 TUČEK, Karel. Program vlastivědných museí. Časopis Národního musea (ČNM), 1948-50, roč. 117-119, s. 113.

31 MZA, fond B 124 Krajský národní výbor Brno, karton 590, složka 368/1, fol. 17-20

32 MZA, SOkA Znojmo, fond Jihomoravské muzeum Znojmo (1945-2002), karton 8, i. č. 451 složka: Zřizování obraz. galerií, stav uměl. sbírek 1950, a i. č. 453, složka: Zpráva o potřebách muzea-vybavení personální a prostorové 1952, Zpráva o potřebách musea ve Znojmě (15. 4. 1952), nefoliováno.
} 
Prezentace vyzdvihovala zvláště ta zvířata, jež měla zásadní vliv na socialistické hospodářství jako například ryby, dobytek a drůbež. Vedle toho se objevila připomínka sovětských výzkumů a úspěchů. Do výše zmíněné linky inspirované rámcovým programem se pak zasazovaly zvláštnosti přírody Znojemska.

Koncepci historického oddělení v prvním patře Frohnfestu zase ovlivnil historický materialismus a periodizace dějin Václava Husy. Základní ideou bylo zasazení lokálních dějin do obecného historického vývoje, jak jej popisoval rámcový program. První dvě místnosti se věnovaly historickým geologickým procesům Znojemska s nezbytným přesahem do socialistického hospodářství. Expozice tak ukazovala využití kaolinu, lomového kamene a štěrků v regionu. Třetí místnost seznamovala návštěvníky s pravěkem na Znojemsku. Expozice pak pokračovala chronologicky v mezích marxistické historiografie od feudalismu přes kapitalismus až po socialismus, respektive po socializaci vesnice. V jedné linii se tak objevila například vzpoura znojemských řemeslníků z roku 1338, husitské hnutí v regionu, selská povstání až do posledního v roce 1821 i formování dělnického hnutí a jeho projevy. Drlík k tomu zdůrazňoval českou nacionální linku, v níž prezentoval dějiny Znojma jako eschatologický vývoj etnicky české společnosti kráčející k definitivnímu ovládnutí města a k socialismu. Zmíněné ideové schéma samozřejmě doplňovaly nezbytné výstavní prvky, tj. mapy, diagramy a fotografie. Přes obtíže s materiálem se nakonec podařilo nové expozice otevřít veřejnosti v dubnu $1952 .^{33}$

33 MZA, SOkA Znojmo, fond Jihomoravské muzeum Znojmo (1945-2002), karton 1, i. č. 51, složka: Plán reorganizace muzea 1951; MZA, SOkA Znojmo, fond Jihomoravské muzeum Znojmo
Znojemské muzeum patřilo mezi vůbec první takové pamětové ústavy, které přistoupily k přebudování stálých expozic v poúnorovém diskursu. To neuniklo pozornosti angažovaných muzejníkù, kteří znojemské muzeum dávali za př́klad jiným. Zoroslava Drobná popsala v Časopisu národního musea ještě nehotové instalace a chválila za uplatnění marxistických zásad a pokrokových prezentačních technik. Jen na okraj se zmínila, že dispozice minoritského kláštera s malými místnostmi není zcela vhodná pro takovou instalaci. ${ }^{34}$

Až do začátku roku 1951 se v krajinském muzeu pokračovalo s opravami budovy zámku a s postupným rozšiřováním expozic. Jech a jeho spolupracovníci stále uplatňovali tradiční ostenzi, v níž každá místnost prezentovala nějaký vědní obor, umělecké památky nebo památkově interiérovou instalaci. Sousedící expozice navíc na sebe často nenavazovaly. ${ }^{35}$ I přesto se v muzejním spolku ozval ojedinělý hlas inspirovaný rámcovým programem. V květnu 1950 na zasedání kuratoria vystoupil František Pol, Jechův aktivní spolupracovník a člen KSČ, $\mathrm{s}$ přednáškou o poslání a smyslu muzea, které „nemá být snůškou kuriosit, ale má podávat přehled kraje $e^{36} \mathrm{~K}$ tomu vyzdvihoval lidovýchovnou úlohu a na konci vyzval k vybudování vzorového

(1945-2002), karton 8, i. č. 452, složka: Zpráva o zpř́istup. muzea (po reorg) 1952.

34 DROBNÁ, Zoroslava. Připravovaná historická instalace v Městském museu ve Znojmě. ČNM, oddíl věd společenských, 1951, roč. 120, s. $119-121$

35 K expozicím v prvním poschodí a k řemeslným dílnám MZA, SOkA Třebíč, fond Krajinské muzeum Moravské Budějovice, Kniha Zápisy o schůzích kuratoria měst. Musea v Mor. Budějovicích, zápis ze 14. 5. 1950; k přízemí viz ibidem, zápis z 9. 5. 1949.

36 MZA, SOkA Třebíč, fond Krajinské muzeum Moravské Budějovice, Kniha Zápisy o schůzích kuratoria měst. Musea v Mor. Budějovicích, zápis ze 14. 5. 1950. muzea. Pol však nedokázal překonat Jechovu autoritu, nebot jeho výzva nenašla ohlas a expoziční práce pokračovaly v původní koncepci.

Místní organizace KSČ začala řešit nesoulad muzejního spolku s novou kulturní politikou v březnu 1951. MNV využil článek spolkového řádu o podřízenosti kuratoria místní správě, který paradoxně prosadil Jech v roce 1946, a oznámil, že plánovaná valná hromada spolku se již nebude konat. Místo ní jmenoval MNV muzejní komisi řízenou Bohumilem Vejtasou, kulturním a osvětovým referentem MNV, Františkem Petrem a Janem Korandou. Ostatní funkce si komise mohla už zvolit sama dle libosti. Dosavadní předseda František Novák se tak stal místopředsedou a Jech zůstal správcem muzea. ${ }^{37}$ Muzejní spolek pak zanikl v ř́ijnu 1951 na základě zákona o dobrovolných organizacích.

Vrchol Jechovy práce přišel ve chvíli, kdy se nezadržitelně měnila atmosféra $\mathrm{v}$ regionu. V neděli 13. května 1951 se otevřely veřejnosti všechny plánované expozice. Jen pět dní před slavnostním otevřením zatkla Státní bezpečnost děkana Opletala, bývalého člena kuratoria. ${ }^{38}$ Zakrátko v červenci vyvrcholilo napětí babickými vraždami a následnou vlnou komunistických represí v širokém okolí.

Zásahy úřadů se projevily i v expozicích. Na podzim roku 1951 navštívil muzeum Karel Havlena, referent školství a kultury Krajského národního výboru (KNV) v Jihlavě. Při té příležitosti nařídil Jechovi odstranit bustu Františka Staňka, velkostatkáře z nedaleké

37 MZA, SOkA Třebíč, fond Krajinské muzeum Moravské Budějovice, Kniha Zápisy o schůzích kuratoria měst. Musea v Mor. Budějovicích, zápis ze 13. 3. 1951 a 16. 4. 1951.

38 MVT - PMB. JECH, František. Pamětní kniha Moravských Budějovic III/2 (1945-1955), s. 464, fotokopie. 
Želetavy, prvorepublikového poslance a ministra, a fotografii zmíněné osobnosti s prezidentem Masarykem. V prosinci 1951 se do muzea dostavili čtyři př́slušníci Sboru národní bezpečnosti, aby údajně vykonali provozně bezpečnostní prohlídku budovy. Pečlivě prohledali celé muzeum od trámů na půdě, přes vitríny až po tmavé kouty ve sklepích, protože ve skutečnosti pátrali po zbraních. Jeden ze strážmistrů chabě kryl celou akci sepisováním požárně bezpečnostních závad. Na konci prohlídky však nalezli př́slušníci jen 11 palných zbraní, které mělo muzeum nechat znehodnotit. ${ }^{39}$

\section{Systematizace muzeí}

V první polovině 50 . let se obou muzeí citelně dotkla systematizace muzejní sítě. Zdálo se, že státní moc tak vyslyšela dlouhodobý požadavek muzejních odborníků, ovšem celou strukturu přizpůsobila především pro snazší kontrolu. Krajská muzea, včetně nově zrrízeného jihlavského a bývalého Moravského zemského muzea, měla zajištovat vědeckou a metodickou práci, zatímco okresní ústavy, nově podřízené okresním národním výborům (ONV), se měly soustředit na propagandistickou činnost.

Na počátku března 1953 převzal ONV Znojmo od MNV celé muzeum do správy a změnil název i ředitele. ONV s okamžitou platností jmenoval do vedení Okresního muzea ve Znojmě Antonína Hudce, zaměstnance krátce předtím uvolněného $\mathrm{z}$ okresního soudu. ${ }^{40}$ Drlík ze svého sesazení

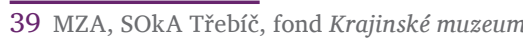
Moravské Budějovice, Kniha Musejní deník práce I, zápis ze 6. 10. 1951 a zápis z 13. 12. 1951.

40 Antonín Hudec, vyučený znojemský

holič, v mládí projevil dobrodružnou povahu. Prošel španělskou občanskou válku jako interbrigadista, za druhé světové války se dostal do řad československého zahraničního vojska ve Velké Británii. Po návratu se z něj stal aktivní komunista a znojemský funkcionář lidových milic. Na přelomu 40. a 50. let prošel muzeologickým školením Svazu českých muzeí. obviňoval Hudce, jeho vazby na ONV a na bývalé spolubojovníky $\mathrm{z}$ interbrigád, kteř́i se uchytili v mocenském aparátu. Jak naznačuje Drlíkova nevyslyšená stížnost, spor obou mužů měl dlouhodobý charakter a odrážela se v něm rivalita místních orgánů KSČ. Drlík se v ní snažil zpochybnit Hudcův charakter, odbornost i jeho komunistickou minulost v předválečném Znojmě. ${ }^{41}$ Drlík v muzeu setrval jako Hudcův podřízený téměř až do své smrti $\mathrm{v}$ roce 1955.

Nový ředitel hodlal zasáhnout do nedávno zhotovených expozic. Na základě reakce delegace z ministerstva kultury a brněnského KNV usoudil, že přírodovědná prezentace již nevyhovuje nárokům a bude ji třeba reinstalovat. K tomu považoval Frohnfest za nevhodnou budovu pro výstavy, proto z něj chtěl vytvořit depozitár a na hradě vybudovat vzorové expozice. Kritika zástupců KNV a ministerské delegace vycházela z nového radikálnějšího požadavku na muzejní prezentace.

Rámcový program, podle nějž byla vybudována sotva dva roky stará Drlíkova expozice, považovalo ministerstvo a jemu fakticky podřízené vedení Svazu českých muzeí za nevyhovující. Již v listopadu 1950 nastínil Jaroslav Charvát, marxistický historik a zástupce Ministerstva školství, věd a umění, že rámcový program je nedostatečný. ${ }^{42} \mathrm{~V}$ červenci 1952 na sjezdu v Českých Budějovicích vystoupil Ferdinand Prantl, vědecký pracovník Národního muzea, který ve svém př́ispěvku také apeloval, aby muzea uplatňovala expozice a výstavy

\footnotetext{
41 MZA, SOkA Znojmo, fond Jihomoravské muzeum Znojmo (1945-2002), karton 11, i. č. 734, složka: Vratislav Drlík - správce muzea 1952-1953-1980, fol. 4-6.

42 CHARVÁT, Jaroslav. Úkoly našich museí v socialistické společnosti. ČNM, 1948-50, roč. 117-119, s. 5-10.
}

$\mathrm{k}$ převýchově. Prantl to shrnul do teze, že: „Pokrokové musejnictví musí se snažit o vystavování, resp. dokumentaci myšlenky - ideje.“43 Naléhavost výzvy k reinstalaci expozic ještě podtrhla sjezdová rezoluce, požadující boj proti „názorovým přežitkům, proti objektivismu a kosmopolitismu" skrze nové instalace a putovní výstavy. ${ }^{44}$ Žádanou podobu muzeí pak představila příručka Musea slouží lidu se vzorovým libretem $\mathrm{v}$ roce $1954 .{ }^{45}$

\section{Z Hudcova záměru vybudovat} aktuálně odpovídající instalaci se nakonec zrealizoval jen zlomek. V letech 1955 až 1956 zaměstnanci postupně vyklízeli na Znojemském hradě výstavní prostory i depozitáře, aby zde mohla proběhnout stavební rekonstrukce. Poté zde vznikla smíšená expozice, $\mathrm{v}$ níž $\mathrm{v}$ přízemí byla zrrízená památkově interiérová instalace s mobiliářem od baroka až po biedermayer a $\mathrm{v}$ jednom sálu numismatická výstava. $\mathrm{Na}$ hradě vznikl i nový prostor pro př́ležitostné výstavy. ${ }^{46}$

$\mathrm{V}$ roce 1957 se vedení muzea rozhodlo reinstalovat př́rodovědné oddělení, které mělo být nově v přízemí Frohnfestu. Nová expozice měla kombinovat geologické, botanické a zoologické poměry na Znojemsku včetně zobrazení zdejších hospodářských odvětví. Hlavním lákadlem mělo být velké akvárium o objemu $25 \mathrm{~m}^{3} \mathrm{a} v$ něm

\footnotetext{
43 PRANTL, Ferdinand. Boj proti kosmopolitismu a objektivismu v českém musejnictví. ČNM, 1952, roč. 121, č. 2, s. 107.

44 DENKSTEIN, Vladimír. Musejní sjezdy v Čechách a na Slovensku. ČNM, 1952, roč. 121, č. 2, s. 156-159.

45 V ní mimo jiné kritizovali laxnost mnoha muzejních pracovníků i MNV k přeměně instalací na základě marxleninské ideologie. DENKSTEIN, Vladimír, František MATOUŠ a Karel TUČEK. Musea slouží lidu. Příručka pro musejní a vlastivědné pracovníky. Praha: Orbis, 1954, s. 30-31.

46 MZA, SOkA Znojmo, fond Jihomoravské muzeum Znojmo (1945-2002), karton 7, i. č. 336-339, složka: 1953, fol. 3-19.
} 
veškeré sladkovodní ryby českých tekoucích i stojatých vod. ${ }^{47}$ Plány se však dlouhodobě nedařilo naplnit a místo unikátní expozice vzniklo zanedbané staveniště. $\mathrm{V}$ roce 1962 si zaměstnanec Vědomil Vildomec stěžoval, že tímto tempem nebude nová expozice hotová ani $\mathrm{v}$ roce $1970 .{ }^{48}$

Obdobný osud jako akvárium potkal i takzvanou Pamětní síň I. a II. odboje. Ta vznikla na hradě již za první republiky jako oslava legionářů a po roce 1945 přibyla do obnovené síně připomínka protinacistického odboje. Po únorovém převzetí moci ji nechal Drlík ideologicky upravit až po veřejné kritice, že si síň uchovává prvorepublikovou a prozápadní interpretaci. Z pamětní síně zůstalo torzo, které Hudec doplnil místními komunistickými mučedníky, nezbytným Stalinovým citátem a fučíkovským: „Lidé, bděte!“. Hudec sám byl ale přesvědčen, že síň do muzea nepatří, a tak využil rekonstrukce hradu pro její zrušení. V říjnu 1955 neúspěšně navrhl, aby se sín stala součástí významné budovy MNV, ONV nebo okresního výboru KSČ. Posléze přistoupil na myšlenku, že pamětní síň vznikne $\mathrm{v}$ přízemí minoritského kláštera se samostatným vchodem. V Hudcových velikášských návrzích síň nápadně připomínala sakrální prostor. Celý prostor měl mít čtyři vitrážová regotizující okna $s$ výjevy z bojišt a koncentračních táborů. Centrem měl být takzvaný oltář vlasti se jmény padlých a umučených a tumba s ostatky neznámého vojína. Podlahu, stěny i strop mělo zdobit mramorové obložení. Zvláště strop měl být vyložený blankytně modrým kamenem s malým státním znakem

47 MZA, SOkA Znojmo, fond Jihomoravské muzeum Znojmo (1945-2002), karton 6, i. č. 301-304, složka: Rámcový výhledový plán úkoli̊ Jihomoravského musea ve Znojmě za rok 1957. 48 MZA, SOkA Znojmo, fond Jihomoravské muzeum Znojmo (1945-2002), karton 8, i. č. 461, složka: Zpráva o stavu muzea v 1. 1945-1962, „Rozvoj“ Jihomoravského muzea ve Znojmě. a znakem města Znojma. Celek pak v návrhu doplňovaly čtyři lunety s vyobrazením slavných odbojových okamžiků. Hudec požadoval, aby financování zajistila Státní památková správa. ${ }^{49}$

\section{$\mathrm{V}$ roce 1957 se přistoupilo} k realizaci Pamětní síně národního odboje, avšak právě financování se ukázalo jako největší slabina. Státní památková správa nemohla být investorem vzhledem k nové památkové legislativě, zátěž tak padla na MNV a ONV. ${ }^{50}$ Nedostatek financí vedl nakonec k utlumení prací. Hudcova megalomanská vize byla definitivně odmítnuta v roce 1969 právě kvůli nereálným nákladům. ${ }^{51}$

Moravskobudějovický ústav prošel reorganizací o rok dříve než znojemský. Počátkem roku 1952 přešlo krajinské muzeum z MNV pod ONV Moravské Budějovice. Novým správcem byl jmenován František Pol, kterého uvolnili z okresního soudu, a stal se vůbec prvním placeným zaměstnancem muzea. Jech v muzeu zůstal i nadále. ${ }^{52}$ Důvod výměny byl nasnadě. Regionální buňka KSČ vnímala dosavadního správce jako zástupce „staré elity“ z dob masarykovského Československa a navíc Jech byl věřící člověk. Na začátku Polova působení došlo k přejmenování na Okresní muzeum ${ }^{53}$ a přeměně výstavní síně

49 MZA, SOkA Znojmo, fond Jihomoravské muzeum Znojmo (1945-2002), karton 18, i. č. 1318, složka: Pamětní síň národního odboje 1955-1973, fol. 9-10.

50 Ibid., fol. 46-47.

51 Ředitel muzea Vildomec v té době již prosazoval střízlivé muzejní pojetí. Viz ibid., fol. 82

52 MVT - PMB. JECH, František. Pamětní kniha Moravských Budějovic III/2 (1945-1955), s. 478, fotokopie; LOJDA, Vladimír. Muzeum v Moravských Budějovicích. Brno: Masarykova univerzita, Filozofická fakulta, Ústav archeologie a muzeologie, 2011, s. 31. Magisterská diplomová práce.

53 MVT - PMB. JECH, František. Pamětní kniha Moravských Budějovic III/2 (1945-1955), s. 480, fotokopie. v přednáškový sál Osvětové besedy. První akcí byla přednáška Atomová energie a mírové využití. ${ }^{54}$

V dalších letech muzejní expozice stagnovaly. Instalace si fakticky udržovaly konzervativní strukturu, kterou jim vtiskl Jech až na nezbytné ideové úpravy. Pol se vedle přednáškové činnosti soustředil ještě na dočasné výstavy, čímž se muzeum definitivně proměnilo $\mathrm{v}$ propagandistický nástroj. Pol se věnoval muzejní práci až do roku 1957, kdy byl zvolen předsedou MNV. ${ }^{55}$ Jeho nová funkce mu nedovolovala se aktivně podílet na činnosti okresního muzea, přičemž si nezajistil ani nástupce. Krizi instituce prohloubil navíc zásah ONV, který prosadil přes Polův nesouhlas, aby se okresní knihovna přemístila do třech velkých místností v budově zámku na konci ledna 1959.56 Reorganizace státní správy v roce 1960 definitivně uspíšil zánik Okresního muzea, nebot Okres Moravské Budějovice byl zrušen. Poté zbývající expozice, depozitář i sbírky zůstaly nepřístupné až do převzetí Západomoravským muzeem Třebíč v 70. letech.

\section{Strnulá expozice}

moravskobudějovického muzea nepatřila mezi výjimečné případy. V druhé polovině 50. let mnohá muzea základní úrovně reflektovala jen minimálně požadavek reinstalací v marxleninské koncepci z let 1950-56. V jejich expozicích setrvávala tradiční ostenze, připomínající skladiště či otevřený depozitár. ${ }^{57}$

\footnotetext{
54 MZA, SOkA Třebíč, fond Krajinské muzeum Moravské Budějovice, Kniha Musejní deník práce I, zápis z 29. 4. 1952.

55 MVT - PMB. POL, František. Pamětní kniha Moravských Budějovic IV (1955-1959), s. 3, fotokopie., s. 48 a 90.

56 Ibid., s. 161.

57 Jedním z příkladů toho, že požadavek změny muzejních expozic často zůstával na papíře, je kritika muzeí v Sobotce a Jilemnici. KAVAN, Jaroslav. Komu není rady... Naše vlast. Časopis pro vlasteneckou práci, 1958, roč. 6, č. 1, s. 2.
} 


\section{Dočasné výstavy a další osvětové aktivity}

Krátkodobé výstavy měly být od počátku podstatným příspěvkem muzeí na cestě $\mathrm{k}$ vytvoření nového socialistického člověka. V dubnu 1948 to jasně formuloval Jiří Müller, muzejník z Náprstkova muzea a jeden z řečníků na Sjezdu národní kultury, zdůraznil, že páteří lidovýchovné činnosti mají být nově dočasné výstavy. $\mathrm{Na}$ nich mají rezonovat aktuální témata, která přitáhnou zájem veřejnosti a nabídnou ,poutavou formou vědecky správné poučení k současným domácím i světovým událostem kulturním, sociálním i politickým“. 58

V listopadu 1950 na pracovním setkání zestátněných muzeí v Bechyni vyvstal požadavek na Svaz českých muzeí, aby vyzval své členy k uspořádání nejméně dvou budovatelských výstav v roce $1951 .{ }^{59}$ Svaz vyhověl a doporučil muzeím kromě samotné akce i jednotlivá témata jako například Plnění pětiletého plánu a jeho výsledky, Pokroky mechanizace $v$ zemědělství, Horníci kdysi a dnes, Úspěchy jednotné školy, Boj o mír, Znárodněný průmysl základem blahobytu, Třicet let KSČ, Socialistická výstavba našeho zemědělství nebo Jiráskův rok. ${ }^{60}$

Dalším pokusem jak vzbudit zájem o uspořádání angažovaných výstav měly být různé aktuální události

Svaz muzeí a ministerstvo kultury se snažilo podnítit změnu metodou socialistické soutěže. V roce 1957 např́iklad svaz vyhlásil soutěž o „Nejlepší exposice okresního vlastivědného musea 1957“. Na krajské úrovni měla rozhodova o vítězi již plně etablovaná krajská muzea. Výzva okresním museím k soutěži. Naše vlast. Časopis pro vlasteneckou práci, 1957, roč. 5, č. 6, s. 91.

58 Sjezd národní kultury 1948. Sbírka dokumentů. Praha: Orbis, 1948, s. 289

59 DENKSTEIN, Vladimír. Odborně politické školení musejních pracovníků. ČNM, 1948-50, roč. 117-119, s. 128-129.

60 DENKSTEIN, Vladimír. Budovatelské výstavy v českých museích v r. 1951. ČNM, 1948-50, roč. 117-119, s. 129. a výročí. Svaz muzeí například vyhlásil na rok 1955 soutěž o nejlepší výstavu k 10. výročí osvobození vlasti, do níž se zapojilo 171 z 324 vlastivědných muzeí. Jedním ze záměrů soutěže bylo mimo jiné to, aby se tyto dočasné instalace staly základem nových expozic výstavby socialismu. ${ }^{61}$ Problematice výstav se věnoval především Karel Tuček, který nabádal k tomu, aby kvalitní výstavě předcházela konzultace libreta s místními osvětovými besedami a masovými organizacemi, čímž se mělo zajistit především správné ideologické hledisko. Dále měli autoři záměru koordinovat témata s kulturně osvětovými plány příslušné ONV, oprostit se od zbytečných dekorací a u výstav s přesahem do současnosti předložit přesvědčivé doklady pokroku. ${ }^{62}$

Jihomoravské muzeum ve Znojmě, jak zněl nový název od května 1954, pokračovalo dál v předúnorovém pořádání výstav. Ročně dokázali pracovníci zorganizovat tři až pět takových projektů a k tomu ještě menší, často propagandisticky laděné, výstavky. Většina z nich ovšem měla umělecký, nebo historicky vlastivědný charakter. Například v roce 1953 připravilo muzeum výstavu grafik Maxe Švabinského, o tři roky později zase soudobé regionální výtvarníky, výstavu o vývoji znojemské keramiky nebo o husitské minulosti v Jevišovicích. ${ }^{63}$ Mezi nejvýznamnější muzejní akce tohoto období patřily bezesporu oslavy 200. let od vynálezu bleskosvodu Prokopa Diviše.

61 PICMAUS, K. Oddělení socialistické výstavby v našich museích. Naše vlast. Časopis pro vlasteneckou práci, 1956, roč. 4, č. 3, s. 43-44.

62 TUČEK, Karel. Příležitostné výstavy vlastivědných museí. Naše vlast. Časopis pro vlasteneckou práci, 1953, roč. 1, č. 5, s. 135-137.

63 K výstavám jednotlivé zprávy v MZA, SOkA Znojmo, fond Jihomoravské muzeum Znojmo (1945-2002), karton 7, i. č. 336-339, složka: 1953, fol. 1-21.
Jejich součástí byla nejen výstava, ale i odhalení pamětní desky na budově bývalé jezuitské koleje a vydání pamětní medaile. Je nutné podotknout, že výstavní architektura se neobešla bez dekorativně zhotovených citátů Lenina, Klementa Gottwalda a Václava Kopeckého. ${ }^{64}$

Největším ideologicky zabarveným počinem byla výstava k 10. výročí osvobození Československa, uspořádaná na popud svazu muzeí. Jihomoravské muzeum jí vyhradilo tři hradní sály. Vstupnímu prostoru vévodila sádrová plastika přivítání rudoarmějců s patřičně velikým oslavným heslem a za ním následovala místnost $\mathrm{s}$ připomínkou nacistické okupace a odboje. V hlavním sále se prezentovalo dosídlení Znojemska, úspěchy KSČ a zvláště únor 1948 jako dějinný mezník. Od tohoto milníku se pak prezentovaly současné úspěchy v průmyslu, zemědělství, školství, zdravotnictví apod. Tematická linka se opírala o stereotypní schéma vzestupu z „temné doby“ před brány socialismu pomocí srovnávání minulosti a současnosti. I budoucí osud výstavy sledoval instrukce muzejních autorit. Po skončení se z výstavní stala trvalá expozice výstavby socialismu. ${ }^{65}$ Muzeum za uspořádání výstavy získalo navíc od svazu čestné uznání a zaměstnanci věcné odměny. ${ }^{66}$

Nezůstalo pouze u výstav. V polovině 50. let Hudec vzkřísil vlastivědný kroužek pro mládež, zájemce a přátele muzea. Kroužek pořádal každoročně několik

64 K oslavám vynálezu Prokopa Diviše MZA, SOkA Znojmo, fond Jihomoravské muzeum Znojmo (1945-2002), karton 19, i. č. 1320, složka: Jubilejní výstava P. Diviše 1954.

65 MZA, SOkA Znojmo, fond Jihomoravské muzeum Znojmo (1945-2002), karton 19, i. č. 1320, složka: Výstava k 10. výročí osvobození ČSR 1945, 1955, fol. 4.

66 PETRÁŇ, Josef. Drobnosti ze života museí. Naše vlast. Časopis pro vlasteneckou práci, 1956, roč. 4 , č. 10 , s. 151. 
desítek akcí, nejčastěji přednášky, exkurze a vlastivědné vycházky. Program se neomezoval jen na přírodovědná, historická nebo archeologická témata. Malá část akcí měla ryze ideologický nádech jako například Hudcova přednáška o španělské občanské válce, beseda s pamětníky dělnického hnutí nebo přednáška o vlivu říjnové revoluce na české dělnictvo. Bohatý program s menšinou zpolitizovaných akcí napomohl tomu, že si kroužek udržoval vysokou popularitu a sloužil jako vzor jiným muzeím. ${ }^{67}$

Moravskobudějovické muzeum se začalo věnovat dočasným výstavám soustavněji až od roku 1949 a to ještě tak, že většinu $\mathrm{z}$ nich ani neorganizovalo a jen poskytovalo prostor. $\mathrm{Za}$ rok 1949 tak v muzeu a jeho areálu proběhly tři výstavy, z nichž dvě neměly ani muzejní charakter. Začátkem června 1949 proběhl první ročník výstavy drobného zvířectva na zámeckém nádvoří, v záŕí pak v muzeu výstava ovoce, obilí, květin a hospodářských strojů a $\mathrm{v}$ prosinci prezentace současných regionálních malířů ${ }^{68}$ Tento trend pokračoval i v dalších letech. Např́lklad v roce 1950 Jech uspořádal výstavku k 5. výročí osvobození země a umožnil filatelistickou výstavu, ${ }^{69}$ Vildomcovu výstavu prezentující archeologické nálezy z okolí řeky Želetavky a pracovníkům

67 K vlastivědnému kroužku a jeho aktivitám MZA, SOkA Znojmo, fond Jihomoravské muzeum Znojmo (1945-2002), karton 43, i. č. 2082-2107, složka: Vlastivědný kroužek při JMM; k jeho prezentování jako vzoru například ANDROVIČ Štefan. Ve Znojmě besedují. Naše vlast, 1956, roč. 4, č. 8, s. 126; HUDEC, Antonín. Zkušenosti vlastivědného kroužku ve Znojmě. Naše vlast. Časopis pro vlastivědnou práci, 1957, roč. 5, č. 5, s. 75 .

68 MZA, SOkA Třebíč, fond Krajinské muzeum Moravské Budějovice, Kniha Musejní deník práce I, rok 1949.

69 V deníku se uvádí ještě třetí výstava tzv. sín želetavských památek, která měl ovšem trvalý expoziční charakter. MZA, SOkA Třebíč, fond Krajinské muzeum Moravské Budějovice, Kniha Musejní deník - práce I, zápis ze 14. 5. 1950.
Moravského muzea instalovat putovní výstavu Vítězslav Novák a Morava. ${ }^{70}$ Vedle toho se objevily dvě externí ideologické výstavky Sovětské knihy a Dějiny SSSR v obrazech. ${ }^{71}$

Polưv nástup do muzea přirozeně znamenal nástup politicky angažovaných výstav. V březnu 1952 se například konala týdenní propagandistická výstava Babice. První den ji navštívili delegáti okresní konference KSČ a v týdnu pak školy. ${ }^{72} \mathrm{~V}$ roce 1952 se v muzeu otevřely dvě další dočasné výstavy. První byla věnovaná výročí Mikoláše Alše a druhá jednotným zemědělským družstvům na okrese. ${ }^{73}$ Následující roky přebíral prezentační činnost sousední Osvětový dům, který velmi aktivně organizoval výstavy různého charakteru od zemědělských až po umělecké. Muzeum se tak ocitlo v pozadí. Výjimku představovala snad jen soutěžní výstava k 10. výročí osvobození Československa v roce 1955. Pol stavěl hlavní výstavní linku na socializaci vesnice, respektive formování sítě jednotných zemědělských družstev. KNV v Jihlavě ocenilo tuto akci pochvalným uznáním. ${ }^{74}$ O rok později Pol uspořádal zřejmě poslední muzejní výstavu o stavebně historickém vývoji města.

70 MVT - PMB. JECH, František. Pamětní kniha Moravských Budějovic III/2 (1945-1955), s. 449-450, fotokopie.

71 MZA, SOkA Třebíč, fond Krajinské muzeum Moravské Budějovice, Kniha Musejní deník - práce I, zápis ze 6. 10. 1951 a zápis z 13. 12. 1951.

72 MZA, SOkA Třebíč, fond Krajinské muzeum Moravské Budějovice, Kniha Musejní deník - práce I, zápis z 30. 3. 1952.

73 MZA, SOkA Třebíč, fond Krajinské muzeum Moravské Budějovice, Kniha Zápisy o schůzích kuratoria měst. Musea v Mor. Budějovicích, zápis ze 13. 3. 1951

74 MVT - PMB. POL, František. Pamětní kniha Moravských Budějovic IV (1955-1959), s. 3, fotokopie.

\section{Závěr}

Klíčovým faktorem pro ovládnutí muzeí se stala personální otázka. Generaci předválečných muzejníků vystřídaly nové kádry, které měly odhodlání směřovat instituce podle stranických instrukcí. Rychlost výměny závisela na významu muzea a na síle regionálních buněk KSČ. Znojemskou instituci formoval komunistický diskurs nedlouho po válce, avšak na konzervativně katolickém Moravskobudějovicku zasáhl krajinské muzeum až od přelomu let 1951 a 1952, kdy proběhla regionem vlna represí uvozena babickými procesy. Tato politika sebou nesla zásadní problém. Do řízení se dostávali často lidé problematičtí osobnostně i odborně.

Osobnosti spjaté s muzeem přirozeně ovlivňovaly i podobu expozic. Během let 1950 až 1952 se Drlíkovi podařilo vybudovat jednu z prvních moderních instalací v zemi podle tzv. rámcového programu zohledňujícího filozofii historického a dialektického materialismu. Jeho následovník Antonín Hudec se marně pokoušel o velkolepou reinstalaci podle nových požadavků svazu muzeí a ministerstva zhmotněných v příručce Musea slouží lidu. Expozice krajinského muzea, postupně budované v letech 1946 až 1951, stály na předválečné koncepci otevřeného depozitáře či památkově interiérové instalace. František Jech totiž stavěl především na své meziválečné muzejní zkušenosti, zároveň jako dobrovolník a všestranně aktivní osobnost neměl př́liš prostoru pro další muzejní vzdělávání. Ani po nástupu Pola a transformaci na okresní muzeum nedošlo ke změně až na menší ideologicky podbarvené zásahy. Expoziční strnulost moravskobudějovického muzea nebyla mezi ostatními okresními a místními muzei žádnou výjimkou. 
Od poválečných let sílila $\mathrm{z}$ ústředních míst výzva pro pořádání dočasných výstav. Po únoru 1948 v nich KSČ viděla jeden z hlavních nástrojů muzeí pro vytváření nového socialistického člověka. Znojemské muzeum pořádalo pravidelně dočasné výstavy již od svého znovuotevření. Měly především umělecký a historický ráz a pouze menšina $\mathrm{z}$ nich měla primárně ideologické poslání. Výstavní činnost v moravskobudějovickém protějšku se objevila až v letech 1948-1949 a byla spíše okrajovou záležitostí. Muzeum často poskytovalo pouze prostor, $\mathrm{v}$ němž výstavu pořádaly jiné subjekty. Polovým nástupem se tématika posunula do propagandistické roviny. Tento prezentační úkol nakonec převzal Osvětový dům.

Jedna z mála úspěšných centrálních kampaní byla výzva na pořádání výstav k 10. výročí osvobození země v roce 1955. Obě muzea se aktivně zapojila a znojemské dokonce $\mathrm{z}$ dočasné výstavy vytvořilo novou expozici budování socialismu.

\section{První dekáda komunistické} nadvlády tedy vedla u obou muzeí ke krizi, z níž se to moravskobudějovické již nevzpamatovalo. Uvolnění, patrné $\mathrm{v}$ muzejnictví $\mathrm{v}$ druhé polovině 50. let, došlo ke znojemskému muzeu až $\mathrm{v}$ první polovině 60. let. Muzeum v Moravských Budějovicích si muselo počkat na svoji renesanci až na konec 70 . let.

\section{PRAMENY A LITERATURA}

Archiv Moravského zemského muzea, fond Moravské zemské muzeum, 1947.

Moravský zemský archiv v Brně, fond B 124 Krajský národní výbor Brno.

Moravský zemský archiv v Brně, fond B 280 Zemský národní výbor Brno. Moravský zemský archiv v Brně, Státní okresní archiv Třebíč, pracoviště
Moravské Budějovice, fond Krajinské muzeum Moravské Budějovice.

Moravský zemský archiv v Brně, Státní okresní archiv Znojmo, fond Jihomoravské muzeum Znojmo (1945-2002).

Muzeum Vysočiny Třebíč - Knihovna Muzea řemesel Moravské Budějovice. JECH, František. Pamětní kniha Moravských Budějovic II/2. (1926-1938), fotokopie.

Muzeum Vysočiny Třebíč - Knihovna Muzea řemesel Moravské Budějovice. JECH, František. Pamětní kniha Moravských Budějovic III/1 (1939-1945), fotokopie.

Muzeum Vysočiny Třebíč - Knihovna Muzea řemesel Moravské Budějovice. JECH, František. Pamětní kniha Moravských Budějovic III/2 (1945-1955), fotokopie.

Muzeum Vysočiny Třebíč - Knihovna Muzea řemesel Moravské Budějovice. POL, František. Pamětní kniha Moravských Budějovic IV (1955-1959), fotokopie.

ANDROVIČ, Štefan. Ve Znojmě besedují. Naše vlast, 1956, roč. 4, č. 8, s. 126. BERÁNEK, Petr. Muzea jako ideologický nástroj v komunistickém Československu v letech 1948-1959. Př́ipadová studie třech moravských muzeí. Brno: Masarykova univerzita, Filozofická fakulta, Ústav archeologie a muzeologie, 2019. Bakalářská práce.

Budovatelský program Gottwaldovy vlády. Praha: Ministerstvo informací, 1946.

ČURDA, Jiří. Vývoj expozic muzea v Moravských Budějovicích od jeho založení po současnost. Brno: Masarykova univerzita, Filozofická fakulta, Ústav archeologie a muzeologie, 2008. Bakalářská diplomová práce.

DENKSTEIN, Vladimír. Budovatelské výstavy v českých museích v r. 1951. Časopis Národního musea, 1948-50, roč. 117-119, s. 129.

DENKSTEIN, Vladimír. Musejní sjezdy v Čechách a na Slovensku. Časopis Národního musea, 1952, roč. 121, č. 2, s. 156-159.

DENKSTEIN, Vladimír. Odborně politické školení musejních pracovníků. Časopis Národního musea, 1948-50, roč. 117-119, s. 128-129.

DENKSTEIN, Vladimír, František MATOUŠ a Karel TUČEK. Musea slouží lidu. Příručka pro musejní a vlastivědné pracovníky. Praha: Orbis, 1954.
DOUŠA, Pavel. Organizace českého muzejnictví 1945-1989. Opava: Slezská univerzita v Opavě, Filozofickoprrírodovědecká fakulta, Ústav historie a muzeologie, 2005. Dizertační práce.

DRLÍK, Vratislav. 70 let musea královského města Znojma. Znojmo: Městské museum ve Znojmě, 1948.

DROBNÁ, Zoroslava. Připravovaná historická instalace v Městském museu ve Znojmě. Časopis Národního musea, oddíl věd společenských, 1951, roč. 120, s. 119-121.

HRUBEC, Karel. Znojemské museum kdysi a dnes. Stráž na Dyji, 1946, roč. I, č. 1, 6. 10. 1946, s. 3.

HUDEC, Antonín. Zkušenosti vlastivědného kroužku ve Znojmě. Naše vlast. Časopis pro vlastivědnou práci, 1957 , roč. 5 , č. 5 , s. 75.

HUSA, Václav. Epochy českých dějin. Praha: Práce, 1947.

CHARVÁT, Jaroslav. Úkoly našich muzeí v socialistické společnosti. Časopis Národního musea, 1948-1950, roč. 117-119, s. 5-10.

Jihomoravské muzeum ve Znojmě. Muzeum brána poznání. Sborník ke 130. výročí založení. Znojmo: Jihomoravské muzeum ve Znojmě, 2008.

ISBN 978-80-86974-03-3.

K výstavě Jihomoravští výtvarníci ve znojemském museu. Stráž na Dyji, roč. I, 1/1946, 15. 9. 1946, s. 4.

KAVAN, Jaroslav. Komu není rady... Naše vlast. Časopis pro vlasteneckou práci, 1958, roč. 6 , č. 1, s. 2 .

KLEJDUS, Julius a Lea MAŇÁKOVÁ. Vratislav Drlík - učitel, přírodovědec a spoluzakladatel Jihomoravského muzea ve Znojmě. Thayensia-Supplementum 1, 2005, s. 3-6. ISSN 1212-3560.

KUSÁK, Alexej. Kultura a politika v Československu 1945-1956. Praha: Torst, 1998.

LOJDA, Vladimír. Muzeum v Moravských Budějovicích. Brno: Masarykova univerzita, Filozofická fakulta, Ústav archeologie a muzeologie, 2011. Magisterská diplomová práce.

MIKULKA, Jiří. K historii Moravského zemského muzea v letech 1945-1949. Časopis Moravského muzea, 1995, roč. 80 , s. 253-261.

Moravsko-Budějovicko. Krajinské museum v Mor. Budějovicích otevřeno. Naše 
demokracie. List Československé strany lidové na jihozápadní Moravě, 1947, roč. 3, č. 39, 10. 10. 1947, s. 4.

PETRÁŇ, Josef. Drobnosti ze života museí. Naše vlast. Časopis pro vlasteneckou práci, 1956, roč. 4, č. 10, s. 151

PICMAUS, Karel. Oddělení socialistické výstavby v našich museích. Naše vlast. Časopis pro vlasteneckou práci, 1956, roč. 4, č. 3, s. 43-44.

PODBORSKÝ, Vladimír. František Vildomec (6. 2. 1878 - 3. 11. 1975). Venkovský učitel, vlastivědný pracovník a věhlasný archeolog. Vědomil Vildomec (27. 9. 1921 28. 12. 1998). Syn věhlasného archeologa, kantor, muzejník, archeolog a kulturněosvětový pracovník. Brno: Ústav archeologické památkové péče $\mathrm{v}$ Brně a Ústav archeologie a muzeologie FF MU v Brně, 2005.

ISBN 80-86399-20-6.

PRANTL, Ferdinand. Boj proti kosmopolitismu a objektivismu v českém musejnictví. Časopis Národního musea, 1952, roč. 121, č. 2, s. 104-109.

Sjezd národní kultury 1948. Sbírka dokumentů. Praha: Orbis, 1948.

SKUTIL, Josef. Sociální a kulturní poslání musea. Svobodné noviny, 9. 9. 1945.

ŠEVČÍK, J. 90 let Jihomoravského muzea. Rovnost, 31. 7. 1968, s. 4.
ŠPÉT, Jiří. Formování a rozvoj socialistického muzejnictví. Praha: Národní muzeum, 1988.

ŠPÉT, Jiří. Formování kulturně politického programu českých muzeí v letech 1945-1954. Muzejní a vlastivědná práce, 1979, roč. 17, č. 2, s. 92-100; 1979, roč. 17 , č. 3 , s. $141-145 ; 1979$, roč. 17 , č. 4, s. 218-227.

ŠPÉT, Jiří. Únor 1948 a české muzejnictví. Časopis Národního muzea, řada historická, 1983, roč. 152, č. 3-4, s. 212-217.

TUČEK, Karel. Program vlastivědných museí. Časopis Národního musea, 1948-50, roč. 117-119, s. 112-114.

TUČEK, Karel. Příležitostné výstavy vlastivědných museí. Naše vlast. Časopis pro vlasteneckou práci, 1953, roč. 1, č. 5, s. 135-137.

VLK, František. Vytváření expozic Muzea Vysočiny Třebíč, Muzea řemesel v Moravských Budějovicích. Moravskobudějovicko. Zpravodaj moravskobudějovického mikroregionu. 2018 , roč. 43 , č. 4, s. $24 ; 2018$, roč. 43 , č. 5, s. 22-23.

Výzva okresním museím k soutěži. Naše vlast. Časopis pro vlasteneckou práci, 1957, roč. 5, č. 6, s. 91.

Znojemské museum. Týdeník pro pohraničí, 1946 , roč. 2, č. 27,6 . 7. 1946, s. 1.
Znojemsko. Výroční zpráva musea král. města Znojma za rok 1947. Naše demokracie. List Československé strany lidové na jihozápadní Moravě, 1948, roč. 4, č. 5, 30. 1. 1948, s. 6.

\section{PETR BERÁNEK}

Muzeum řemesel Moravské Budějovice, Muzeum Vysočiny Třebíč, Česká republika

p.beranek@muzeumtr.cz

Vedoucí moravskobudějovické pobočky Muzea Vysočiny Třebíč. Zabývá se moderními dějinami první poloviny 20. století $s$ důrazem na regionální problematiku a levicová hnutí.

Head of the Museum of Vysočina Region in Třebíč, branch Moravské Budějovice. He is concerned with history of the first half of the 20th century with emphasis on regional problems and left-wing movements. 